\title{
El procedimiento especial sancionador en la reforma electoral de 2014
}

\section{Edmundo Jacobo Molina*}

\section{Sumario:}

I. Orígenes del procedimiento especial sancionador

II. El procedimiento especial sancionador en la práctica: una visión general

III. El procedimiento especial sancionador en la práctica: desarrollo de criterios e implicaciones institucionales

IV. El procedimiento especial sancionador en la reforma constitucional de 2014

V. Conclusión

* Secretario ejecutivo del Instituto Nacional Electoral. Agradezco la colaboración de Camilo Saavedra Herrera, Iván Ramírez de Garay, Ezequiel Bonilla Fuentes, Miguel Ángel López Rodríguez, David Bernal Hernández, Jesús Galindo y Ernesto Azuela Bernal. 
La relación entre elecciones y justicia ha sido particularmente compleja en la historia de México. La célebre polémica entre Ignacio L. Vallarta y José María Iglesias en torno a la posibilidad de que, desde la justicia, se revisara el origen de la legitimidad de las autoridades públicas influyó desde el siglo XIX las definiciones sobre la jurisdicción que los jueces habrían de tener en asuntos electorales. En la construcción del régimen electoral mexicano ese legado continúa ejerciendo una influencia fundamental, a grado tal que para realizar las funciones jurisdiccionales en materia electoral, se diseñó desde la reforma electoral de 1986, una instancia especializada en materia electoral. Este modelo de justicia electoral se incorporó al sistema de justicia federal en 1996. Desde entonces, sus instituciones son responsables de resolver en última instancia los conflictos que se suscitan en la contienda por el poder público. ${ }^{1}$

En los años recientes la pluralidad política del país, que se ha reflejado en las sucesivas transformaciones al régimen constitucional, han permitido la consolidación de un sistema de instituciones y procedimientos que han dado certeza al sufragio y garantizado el ejercicio de los derechos políticos de los ciudadanos. ${ }^{2}$ Así, las elecciones se han convertido en un cauce genuino para la competencia política y la fuente principal del ejercicio legítimo del poder político. Elecciones auténticas, libres y justas naturalmente han propiciado contiendas políticas más complejas y sofisticadas, lo que en no pocas ocasiones ha derivado en una creciente conflictividad entre actores políticos. ${ }^{3}$

Desde sus primeros años, el Instituto Federal Electoral (IFE) fue responsable de la resolución de infracciones a la normatividad electoral a través de procedimientos de carácter administrativo. Sin embargo, la referida sofisticación de las contiendas electorales ha exigido y desarrolla-

1 Sobre el denominado Amparo Morelos, el surgimiento de la tesis de incompetencia de origen y el legado que produjo en el sistema electoral, véase Peza, José Luis de la, "Notas sobre la justicia electoral en México", en Orozco Henríquez, José de Jesús (comp.), Justicia Electoral en el Umbral del Siglo XXI. Memoria del III Congreso Internacional de Derecho Electoral, México, UNAM, Instituto de Investigaciones Jurídicas, 1999.

2 En relación con el cambio político y la transformación institucional en México, véase Becerra, Ricardo et al., La mecánica del cambio político en México, México, Cal y Arena, 2000.

3 Sobre estrategias políticas y justicia electoral, véase Eisenstadt, Todd A., Courting democracy in Mexico: Party Strategies and Electoral Institutions, Nueva York, Cambridge University Press, 2004. 
do complejos instrumentos que permiten procesar los conflictos, a través de mecanismos legales caracterizados por una amplia regulación.

El procedimiento especial sancionador (PES) fue la respuesta a la necesidad de atender con oportunidad los conflictos surgidos en campañas crecientemente competidas y sofisticadas. Para decirlo en palabras del doctor Lorenzo Córdova: "El procedimiento administrativo especial sancionador tiene una naturaleza restauradora del orden legal dentro de un proceso electoral". ${ }^{4}$ Pero ha tenido otro efecto: ha sido un acicate para trasladar el conflicto político a la sede donde se toman las más relevantes decisiones electorales (el Consejo General del IFE), para convertirlo en sí mismo en un instrumento político y, en esa medida, ha influido significativamente en la dinámica y naturaleza de las actividades de la autoridad electoral. ${ }^{5}$

La reforma electoral de 2014, sin embargo, incluyó modificaciones sustanciales que rediseñaron el procesamiento del conflicto entre partidos y, por lo tanto, abrió la puerta a una modificación en el desempeño de la autoridad administrativa en materia electoral. El objetivo de este texto es contribuir a la explicación del desarrollo que ha tenido el PES desde su creación y, con base en ello, advertir las principales implicaciones y retos que surgen de la reciente reforma.

\section{Orígenes del procedimiento especial sancionador}

La reforma constitucional de 1996 por primera vez le confirió a la autoridad administrativa en materia electoral la atribución de tramitar, sustanciar y resolver procedimientos administrativos, así como imponer las sanciones correspondientes, derivadas de infracciones cometidas por partidos políticos, agrupaciones políticas nacionales y observadores electorales. Ya la reforma electoral de 1989-1990, que dio origen al Instituto Federal Electoral, le había dado la atribución de instaurar procedimientos para conocer de las infracciones de los partidos políticos. Sin embargo, según lo establecido en el Código Federal de Instituciones y

${ }^{4}$ Córdova Vianello, Lorenzo, "Naturaleza y prospectiva del procedimiento especial sancionador", Revista Folios, Instituto Electoral y de Participación Ciudadana de Jalisco, núm. 27, 2012, pp. 52-57.

${ }^{5}$ Córdova Vianello, Lorenzo, "La reforma electoral de 2007-2008 cuatro años después. Apuntes para un balance de su instrumentación”, Revista Mexicana de Derecho Electoral, México, núm. 1, enero-junio de 2012. 
Procedimientos Electorales (Cofipe), en sus artículos 38 y 39, el IFE tan solo debía, en su caso, acreditar la falta y comunicarla a la Sala Central del Tribunal Federal Electoral, en quien residía la atribución de imponer o no la sanción correspondiente. ${ }^{6}$

Si la reforma constitucional de 1989-1990 había significado un cambio sustancial del modelo, al conferirle a una autoridad administrativa, el IFE, facultades jurisdiccionales, esta transformación se profundizó aún más con la sentencia de la Sala Superior del Tribunal Electoral del Poder Judicial de la Federación (TEPJF) recaída al recurso de apelación SUPRAP-17/2006. ${ }^{7}$ Esta resolución tuvo su origen en una queja interpuesta por la coalición "Por el bien de todos" ante el Consejo General del IFE, en relación con dos promocionales transmitidos por radio, televisión e Internet que ostensiblemente formaban parte de una "campaña negativa".

En esos promocionales de la coalición "Alianza por México" se asociaba al candidato presidencial de la coalición "Por el bien de todos", Andrés Manuel López Obrador, con un legislador y funcionarios del Gobierno del Distrito Federal a los que se había acusado de incurrir en actos de corrupción. Se acusaba al candidato de mentir con respecto a uno de los valores que pregonaba como parte central de su campaña, la honestidad, y se le conminaba a debatir públicamente sobre este tema. ${ }^{8}$

En respuesta, el 13 de marzo de 2006, la coalición "Por el bien de todos" solicitó se incluyese en el orden del día de la sesión extraordinaria del Consejo General del IFE, programada para celebrarse el 15 de marzo, un proyecto de acuerdo por el que se ordenaría a la coalición "Alianza por México" el retiro de los promocionales por considerarlos contrarios a la Constitución y el Cofipe. Por decisión unánime el Consejo General tomó la determinación de rechazar el proyecto de acuerdo, bajo el argumento de que sólo mediante un procedimiento sancionador, y no a través de un procedimiento administrativo, podía atender la solicitud. Fue en contra de esta decisión que la coalición "Por el bien de todos" interpuso ante la Sala Superior del Tribunal Electoral el recurso de apelación SUPRAP-17/2006, principalmente bajo los siguientes argumentos:

" García Figueroa, Héctor Daniel, "Nota introductoria” a Madrazo Lajous, Alejandro, Génesis del procedimiento especial abreviado ante el Instituto Federal Electoral. Entre la legalidad y la justicia, México, Tribunal Electoral del Poder Judicial de la Federación, 2011, pp. 12 y 13.

7 Véase Madrazo Lajous, Alejandro, op. cit., pp. 15-18.

8 Roldán Xopa, José, El procedimiento especial sancionador en materia electoral, México, IFE, 2012, pp. 11-13. 
a) Al no aprobar el acuerdo, el IFE dejó de cumplir con la obligación que le impone el Cofipe, de velar por los principios de certeza, legalidad, independencia, imparcialidad y objetividad, y vigilar que los partidos políticos actúen en apego a la normatividad.

b) La decisión del Consejo General violó el principio de justicia pronta (artículo 17 constitucional).

c) Resolver mediante el procedimiento sancionador las quejas relacionadas con la difusión de promocionales en medios masivos de comunicación, podría generar un daño irreparable al proceso electoral, pues los plazos son tan amplios que no permiten un remedio oportuno de los daños causados por la infracción; además de que podrían afectarse los principios de equidad e igualdad y mermarse los derechos de los contendientes.

d) Por consiguiente, si la autoridad electoral solo contara con facultades para sancionar y no interrumpir esas conductas ilegales, en los hechos podría estar incentivando la violación de la ley, pues en el cálculo del infractor, el beneficio que le puede traer la conducta ilegal puede ser mayor a la sanción, que solo le será aplicada posteriormente, una vez que la infracción ha surtido su efecto.

La sentencia del procedimiento SUP-RAP-17/2006, del 5 de abril de 2006, confirmó parcialmente los argumentos de la coalición "Por el bien de todos", y al hacerlo modificó en términos sustantivos los alcances de las facultades jurisdiccionales del IFE. En efecto, el Tribunal Electoral determinó que:

a) El IFE contaba con atribuciones suficientes para resolver el asunto expuesto por la coalición "Por el bien de todos".

b) El Consejo General tiene la facultad implícita "de prevenir o corregir la comisión de conductas ilícitas, así como tomar las medidas pertinentes para restaurar el orden jurídico válido y garantizar el debido desarrollo del proceso electoral"."

c) El procedimiento sancionador del artículo 270 del Cofipe no resultaba la vía idónea para ello.

d) No obstante, tampoco un acuerdo administrativo resultaba suficiente, pues no satisfacía todas las formalidades procesales necesarias.

9 SUP-RAP-17/2006, 13. Sobre el desarrollo del TEPJF en cuanto a las facultades implícitas y explícitas del Consejo General, véase Madrazo Lajous, op. cit., pp. 20-23. 
Así, el Tribunal determinó la necesidad de que exista un procedimiento distinto, aunque análogo, al establecido en el artículo 270 del Cofipe, que sea capaz de inhibir oportunamente conductas ilícitas de los partidos políticos en el transcurso de un proceso electoral y, al mismo tiempo, continúe un juicio que permita garantizar la audiencia del denunciado y una adecuada y oportuna defensa. Ahora bien, a juicio del TEPJF, el hecho de que tal procedimiento no estuviera contenido en el Cofipe no obstaba para que el Consejo General del IFE pudiera conocer de estos casos y resolverlos mediante un nuevo procedimiento de ese tipo. ${ }^{10}$

De este modo, en su resolución el Tribunal Electoral ordenaba al Instituto Federal Electoral la instrumentación de un procedimiento especializado que, análogo al establecido en el artículo 270 del Cofipe, fuese más expedito y tuviera ciertas características especiales, entre las que destacan:

- De oficio o a petición de parte (mediante denuncia), el Consejo General deberá requerir a la Junta General Ejecutiva que investigue hechos que constituyan una afectación relevante a los derechos de los partidos políticos, de sus candidatos o el propio proceso electoral federal.

- Recibida la denuncia o solicitud, el Consejo General deberá sesionar a la brevedad posible para resolver sobre su admisión, señalando en su caso el día y hora para la celebración de una audiencia, que deberá realizarse a través del secretario ejecutivo dentro de los cinco días siguientes a la admisión, para el ofrecimiento, admisión y desahogo de pruebas y alegatos.

- Dada la naturaleza sumaria del procedimiento, "sólo son admisibles los medios de prueba que no necesiten ser preparados previamente y se desahoguen por su propia naturaleza": documentales públicas y privadas, técnicas, presuncionales, e instrumental de actuaciones. Las pruebas deberán ser exhibidas junto con el escrito en que se comparece y ninguna aportada fuera del plazo previsto será tomada en cuenta.

- En casos extraordinarios, se podrá ordenar el desahogo de reconocimientos, inspecciones judiciales o pruebas periciales, cuando puedan desahogarse en la audiencia, se estimen determinantes para esclarecer los hechos y la presunta violación lo amerite.

- Salvo en casos debidamente justificados, la Junta General Ejecutiva deberá formular un dictamen dentro de las veinticuatro horas si-

${ }^{10}$ Roldán Xopa, José, op. cit., pp. 12-15. 
guientes a la finalización de la audiencia, sobre el que deberá resolver el Consejo General a la brevedad posible. La resolución deberá ejecutarse en forma inmediata. ${ }^{11}$

Diversas tesis y jurisprudencias ${ }^{12}$ confirmaron y asentaron el sentido de la sentencia del recurso SUP-RAP-17/2006, que reconocía la facultad de la autoridad electoral de ejercer un procedimiento especializado de urgente resolución. La principal diferencia entre este nuevo procedimiento y el tradicional procedimiento sancionador radica en que, como ya se mencionó, el primero, mediante la cesación de los actos irregulares, tiene un objeto esencialmente preventivo e inhibidor, mientras que el segundo tiene una naturaleza coercitiva y sancionatoria. ${ }^{13}$

Dicho de otro modo, en el procedimiento expedito la litis se centra exclusivamente en determinar la procedencia o no de la suspensión de los actos denunciados, con base en un análisis provisional de las pruebas aportadas. Por lo tanto, su resultado no puede tener carácter vinculante para la autoridad electoral administrativa o jurisdiccional en la resolución del procedimiento administrativo sancionador, mucho menos se pretendía que aquél sustituyera a éste.

La reforma publicada en el Diario Oficial de la Federación el 13 de noviembre de 2007 llevó al texto constitucional la existencia del procedimiento expedito, ahora denominado procedimiento especial sancionador (PES) y circunscrito sobre todo a asuntos relacionados con propaganda política electoral y actos anticipados de campaña. La reglamentación del proceso se definió en el libro Séptimo del nuevo Código Federal de Instituciones y Procedimientos Electorales, reformado en enero de 2014. ${ }^{14}$

En sus aspectos torales, el Procedimiento Especial Sancionador mantuvo las características que había definido el Tribunal, con precisiones diversas. En el Cofipe y en el Reglamento de Quejas y Denuncias, expedido por el IFE, se especificó la existencia de medidas cautelares que interrumpen el potencial efecto de un acto ilícito; se definieron las sanciones y los sujetos susceptibles de ser sancionados; se precisaron a detalle las reglas procesales,y se definió que el procedimiento podía ser interpuesto tanto en los órganos centrales como en los distritales del Instituto.

\footnotetext{
11 Ibidem, p. 15.

12 Véanse, por ejemplo, las Jurisprudencias 12/2007, 2/2008, y la Tesis VII/2008.

13 Madrazo Lajous, Alejandro, op. cit., p. 29.

14 Roldán Xopa, José, op. cit., pp. 24-25.
} 
No hace falta aquí abundar en los detalles procedimentales, pero es importante señalar que con la reforma electoral de 2007-2008, el PES se volvió de hecho más expedito: ahora la audiencia de pruebas y alegatos debía celebrarse, en forma oral e ininterrumpida, cuarenta y ocho horas después de admitida la denuncia, plazo que antes era de cinco días como máximo. También cabe mencionar que se dio a la Secretaría Ejecutiva la facultad de proponer a la Comisión de Quejas y Denuncias, dentro de esas cuarenta y ocho horas, la adopción de medidas cautelares en caso de considerarlas necesarias.

Tabla 1

Plazos para la resoluciones de procedimientos sancionadores

\begin{tabular}{|c|c|c|}
\hline Etapa & Ordinario sancionador & Especial sancionador \\
\hline $\begin{array}{l}\text { Presentación de la queja o } \\
\text { denuncia o inicio del pro- } \\
\text { cedimiento oficioso }\end{array}$ & ----- & ----- \\
\hline $\begin{array}{l}\text { Ratificación de la denun- } \\
\text { cia o queja }\end{array}$ & 3 días & $\mathrm{n} / \mathrm{a}$ \\
\hline $\begin{array}{l}\text { Remisión a la Secretaría } \\
\text { Ejecutiva }\end{array}$ & 48 horas & Inmediatamente \\
\hline Prevención & 3 días & No procede prevención \\
\hline Admisión & 5 días & $\begin{array}{c}\text { No se precisa plazo de } \\
\text { manera } \\
\text { expresa }\end{array}$ \\
\hline Medidas cautelares & $\begin{array}{l}24 \text { horas para resolver, } \\
\text { dentro de los cinco días } \\
\text { para admitir }\end{array}$ & $\begin{array}{l}\text { Dentro de las } 48 \text { horas } \\
\text { previstas para la cel- } \\
\text { ebración de la audiencia }\end{array}$ \\
\hline $\begin{array}{l}\text { Emplazamiento y con- } \\
\text { testación }\end{array}$ & $\begin{array}{c}5 \text { días para contestar, pos- } \\
\text { teriores } \\
\text { al emplazamiento }\end{array}$ & $\begin{array}{l}48 \text { horas posteriores a la } \\
\text { admisión. } \\
\text { Audiencia de pruebas y } \\
\text { alegatos }\end{array}$ \\
\hline Investigación & $\begin{array}{l}40 \text { días desde la recep- } \\
\text { ción. Puede ampliarse } \\
\text { hasta por } 40 \text { días más }\end{array}$ & $\begin{array}{l}\text { Se hace con las constan- } \\
\text { cias de autos y el conteni- } \\
\text { do de la audiencia }\end{array}$ \\
\hline Vista con la investigación & 5 días para alegatos & $\begin{array}{l}15 \text { minutos a cada parte } \\
\text { en la audiencia }\end{array}$ \\
\hline Proyecto de resolución & $\begin{array}{l}10 \text { días después de la vista. } \\
\text { Se puede ampliar por } 10 \\
\text { días más }\end{array}$ & $\begin{array}{l}24 \text { horas después de con- } \\
\text { cluida la audiencia }\end{array}$ \\
\hline
\end{tabular}




\begin{tabular}{|c|c|c|}
\hline $\begin{array}{l}\text { Remisión a la Comisión } \\
\text { de Quejas y Denuncias }\end{array}$ & 5 días & $\begin{array}{l}\text { Solo se remiten a la } \\
\text { Comisión medidas } \\
\text { cautelares. El proyecto } \\
\text { de resolución lo remite } \\
\text { directamente la Secre- } \\
\text { taria Ejecutiva al Consejo } \\
\text { General }\end{array}$ \\
\hline $\begin{array}{l}\text { Sesión de Comisión de } \\
\text { Quejas y Denuncias }\end{array}$ & $\begin{array}{l}1 \text { día para convocar a } \\
\text { sesión que debe celebrarse } \\
\text { no antes de } 24 \text { horas }\end{array}$ & $\begin{array}{l}\text { Convocatoria para sesión } \\
\text { dentro de las } 24 \text { horas } \\
\text { posteriores a la entrega } \\
\text { del proyecto de medidas } \\
\text { cautelares }\end{array}$ \\
\hline $\begin{array}{l}\text { En caso de ser rechazado } \\
\text { el proyecto, plazo para su } \\
\text { nueva elaboración }\end{array}$ & 15 días & $\begin{array}{c}\text { En la sesión convocada } \\
\text { el Consejo General debe } \\
\text { resolver }\end{array}$ \\
\hline $\begin{array}{l}\text { Remisión del proyecto } \\
\text { de resolución al Consejo } \\
\text { General }\end{array}$ & No se establece plazo & $\begin{array}{c}24 \text { horas después de la } \\
\text { audiencia }\end{array}$ \\
\hline $\begin{array}{l}\text { Sesión del Consejo } \\
\text { General para resolución }\end{array}$ & $\begin{array}{c}3 \text { días posteriores a la } \\
\text { entrega del proyecto a los } \\
\text { consejeros }^{*}\end{array}$ & $\begin{array}{l}24 \text { horas después de cir- } \\
\text { culado el proyecto }\end{array}$ \\
\hline Tiempo total mínimo & $\begin{array}{c}64 \text { días, } \\
\text { aproximadamente }^{\star *}\end{array}$ & $\begin{array}{l}5 \text { o } 6 \text { días, } \\
\text { aproximadamente }\end{array}$ \\
\hline $\begin{array}{l}\text { Tiempo total estimado } \\
\text { con ampliación de plazos }\end{array}$ & $\begin{array}{c}129 \text { días, } \\
\text { aproximadamente }^{\star * *}\end{array}$ & No aplica \\
\hline
\end{tabular}

Fuente: adaptado de IFE, Informe sobre la implementación de la reforma electoral durante el proceso 2008-2009, México, IFE, 2010.

* En caso de empate por la ausencia de un consejero, se realiza una segunda votación. Si el empate persiste, el proyecto debe ser presentado en sesión posterior.

** Sin ampliación de plazos; sin rechazo del proyecto de resolución y sin empate en la votación.

*** Calculado considerando el rechazo del proyecto de resolución, sin empate en la votación.

El plazo para la elaboración del proyecto de resolución permanece igual - veinticuatro horas después de celebrada la audiencia-, pero la reforma precisa que una vez entregado el proyecto al consejero presidente, dentro de las veinticuatro horas siguientes el Consejo General debe celebrar una sesión de resolución; el Tribunal solo había indicado que esta sesión debía realizarse a la brevedad posible. De comprobarse la infracción, el Consejo debe ordenar la cancelación inmediata de la transmisión o propaganda, el retiro físico de la propaganda o la suspensión de su 
distribución, según sea el caso, así como imponer las sanciones correspondientes. ${ }^{15}$

Al instaurar el PES, la intención de los magistrados electorales, primero, y después de los legisladores, fue mejorar las condiciones de equidad e igualdad en las contiendas electorales. Y, sobre todo, que la autoridad electoral administrativa tuviera las facultades necesarias para intervenir oportunamente y, así, evitar que las violaciones a la ley electoral en materia de propaganda política y actos anticipados de campaña tuvieran efectos irreparables sobre el desarrollo del proceso electoral y los derechos de los afectados. A la luz del conflicto poselectoral de 2006 y la recurrencia de las denominadas campañas negativas o sucias durante aquél proceso electoral, no hay duda de que la instauración del PES era necesaria. Sin embargo, su inclusión dentro de la esfera competencial del Instituto trajo consigo complejidades diversas.

En primer lugar, el hecho de que se diera a una autoridad administrativa como el IFE facultades materialmente jurisdiccionales, para las que constitucionalmente no está diseñada, ha generado dificultades de diversa índole. Si bien es cierto que desde 1996 el Instituto tiene atribuciones para conocer y resolver procedimientos administrativos sancionadores, la materia y la dinámica del PES ha incrementado exponencialmente la complejidad de estos casos. Por definición las campañas políticas son siempre conflictivas, ríspidas, lo que hace muy difícil establecer criterios nítidos que permitan decidir, por ejemplo, si en ciertas circunstancias un promocional que emplea datos estadísticos duros para criticar el desempeño de un gobierno podría, no obstante, considerarse denigratorio; o bien, si puede considerarse, y en qué casos, que una entrevista en un espacio noticioso puede tener fines propagandísticos y no solo informativos. Así, se ha generado una dinámica en la que, casi invariablemente, la parte afectada por las resoluciones del Consejo General las recurre ante el TEPJF, quien a menudo las ha revocado, lo que ha dificultado aún más el establecimiento de criterios firmes y consistentes, en detrimento de la certidumbre jurídica.

En segundo lugar, a esta incertidumbre de criterios se añade el hecho de que existe, durante los procesos electorales, un gran volumen de este tipo de quejas, por tratarse de un procedimiento que busca interrumpir de manera casi inmediata los actos que a juicio de alguno de los partidos

15 Olmeda García, Marina del Pilar y Sánchez Sánchez, Alejandro, "El procedimiento especial sancionador en el sistema electoral mexicano", Revista de Ciencias Jurídicas, núm. 130, 2013, pp. 53-55. 
son violatorios de la normatividad. Esto ha representado para el Consejo General una sobrecarga de trabajo que por sí misma es problemática, pues ha llevado al límite su capacidad de atender este tipo de asuntos.

Más aún, el hecho de que sea una instancia como el IFE la que resuelve este tipo de procedimientos podría - como de hecho sucedió- generar incentivos para la judicialización de las contiendas electorales. A diferencia de las autoridades propiamente jurisdiccionales, en las sesiones siempre públicas del Consejo General del Instituto participan, con derecho a voz, los consejeros de los partidos políticos y las fracciones parlamentarias representadas en el Congreso de la Unión. De tal suerte, la recurrencia con que se han discutido los PES en el Consejo General ha hecho de éste un foro público al que los partidos — contando con la resonancia noticiosa- han recurrido con frecuencia para intercambiar acusaciones.

Contra su lógica constitucional, el máximo órgano directivo del IFE se ha convertido, durante los procesos electorales, en una puesta en escena del conflicto partidista, en una prolongación de los espacios de campaña política, cuando su meta institucional es, más bien, el de dirimir los conflictos entre los partidos políticos. Así pues, la instauración del PES en el IFE tuvo el efecto no intencionado de, por un lado, generar incentivos para la judicialización de la contienda electoral, y, por el otro, ha tenido una consecuencia incómoda: tensar las cuerdas de la relación entre las autoridades electorales y los partidos políticos.

\section{El procedimiento especial sancionador en la práctica: una visión general}

La reforma electoral de 2007-2008 formalizó el procedimiento expedito que había instaurado el Tribunal Electoral del Poder Judicial de la Federación en 2006. Los plazos establecidos en la normatividad correspondiente consiguieron que el periodo para la resolución de los procedimientos especiales fuese explícitamente más reducido que el de los procedimientos ordinarios o también denominados genéricos. Como se observa en la tabla 1, el proceso de resolución de un procedimiento ordinario se extiende de 64 a 129 días, en tanto que uno de carácter especial transcurre entre cinco y seis días aproximadamente.

El acortamiento de plazos implícito en la naturaleza del procedimiento especial permitió que se procesaran con mayor celeridad algunos de los conflictos generados durante los procesos electorales. La gráfica si- 
guiente muestra el crecimiento sostenido del volumen de procedimientos sancionadores que se han presentado ante las instancias administrativas competentes. Durante el Proceso Electoral Federal 1999-2000 se presentaron 358 quejas; seis años después estos procedimientos genéricos ascendieron a 755. A ellos se sumaron 28 casos derivados del procedimiento expedito creado por la Sala Superior del TEPJF en el marco del proceso electoral que dio lugar a la contienda presidencial más competida de la historia.

\section{Gráfica 1}

Procedimientos sancionadores presentados durante procesos electorales

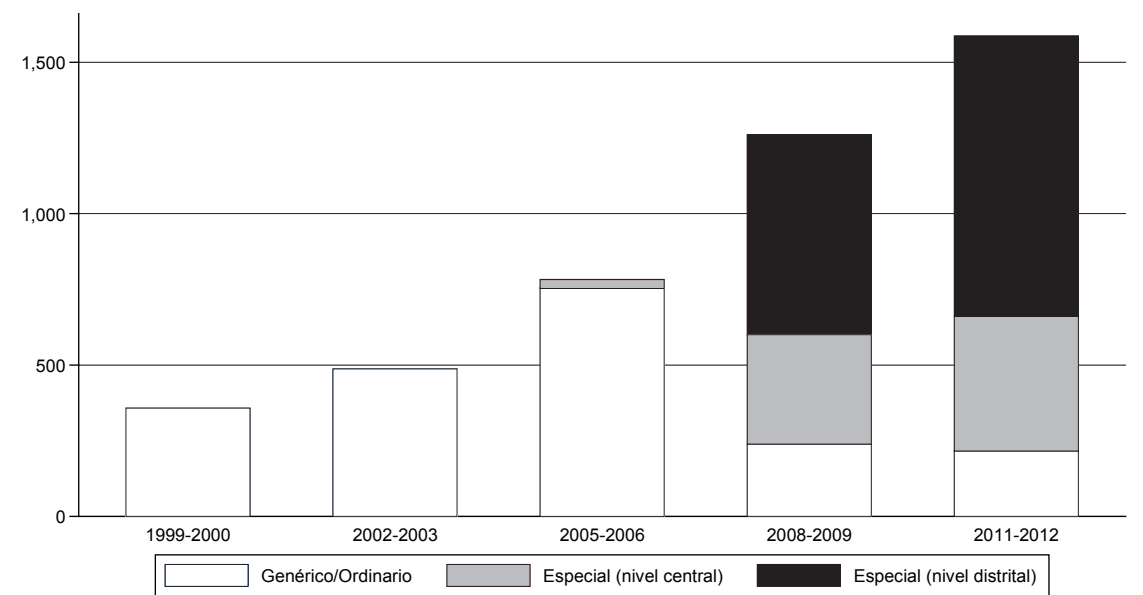

Fuente: elaboración propia con datos de: IFE, Elecciones Federales 2006. Justicia Electoral, México, IFE, 2006; IFE, Informe sobre la implementación de la reforma electoral durante el proceso 2008-2009, México, IFE, 2010; IFE, Memoria del Proceso Electoral Federal 2011-2013, México, IFE, 2013.

El crecimiento constante del volumen de procedimientos sancionadores durante los procesos electorales más recientes no se ha detenido. En 20082009 se iniciaron más de mil doscientos procedimientos y en 2011-2012 esta cantidad fue superior a mil quinientos. En otras palabras, en 20112012, el IFE recibió cuatro veces más casos que doce años antes y dos veces más que seis años antes. Además es revelador observar que este incremento se debe sobre todo a los procedimientos especiales: de hecho la cantidad de procedimientos ordinarios disminuyó sustancialmente de 20052006 a 2008-2009, para mantenerse prácticamente estable en 2011-2012.

A raíz de la formalización del PES se observa una diferencia adicional: la resolución de los casos dejó de efectuarse exclusivamente en el Consejo 
General. En efecto, en los dos últimos procesos electorales dos de cada tres procedimientos especiales sancionadores se presentaron ante instancias distritales.

La resolución de procedimientos sancionadores, particularmente los de carácter especial, ha sido uno de los retos más relevantes que enfrentó el Consejo General del IFE desde su reconfiguración en 2008. Si bien la magnitud de casos bajo su jurisdicción no ha presentado variaciones considerables con respecto a lo que ocurría antes de la reforma electoral de 2007-2008, la complejidad y relevancia de los procedimientos especiales sancionadores y la necesidad de resolverlos con la oportunidad que obliga la ley, ha condicionado la actividad del Consejo General en su conjunto.

En 2008, la nueva integración del órgano máximo de dirección del IFE tuvo que atender un rezago de 443 quejas, de las cuales resolvió ese mismo año $424 .{ }^{16}$ Sumado a ello, desde su incorporación plena al régimen constitucional y legal, el PES se ha convertido no solo en un vehículo relevante para procesar conflictos político-electorales, sino también en un instrumento de las mismas estrategias para contender por el poder político que emplean los partidos.

En este contexto, el Consejo General en calidad de órgano de resolución de los procedimientos especiales, se ha constituido en una caja de resonancia de los conflictos entre partidos. En el Consejo General se han enfrentado los actores políticos que participan en sus sesiones. La máxima autoridad administrativa-electoral de México ha debido constantemente resolver procedimientos de naturaleza jurídico-administrativa en un mesa en la que también participan las partes actoras de los procedimientos. El Consejo General, como se mencionó, se ha convertido en un foro para la escenificación de la contienda partidaria y, por extensión, en una fuente de tensión casi permanente entre la autoridad y los partidos políticos. Pero además la interposición del PES devino en una estrategia para romper las estrategias propagandísticas del o los partidos en lid. Ricardo Becerra lo explica con cierta ironía:

La dinámica es la siguiente: el partido "A" quiere quebrar la estrategia de propaganda del partido "B"; entonces interpone una queja. Un gobernador que pertenece al partido " $\mathrm{C}$ " ha sido denunciado por el partido " $\mathrm{X}$ ", entonces interpone su propia queja contra el Presidente de la República que milita en

${ }_{16}$ IFE, Informe sobre la implementación de la reforma electoral durante el proceso 20082009, México, IFE, 2010 
el partido "C". Lo que hemos visto son mecánicas propagandísticas más o menos enrevesadas que desnaturalizan la índole de la justicia electoral. ${ }^{17}$

Gráfica 2

Procedimientos especiales sancionadores por actor, 2008-2013

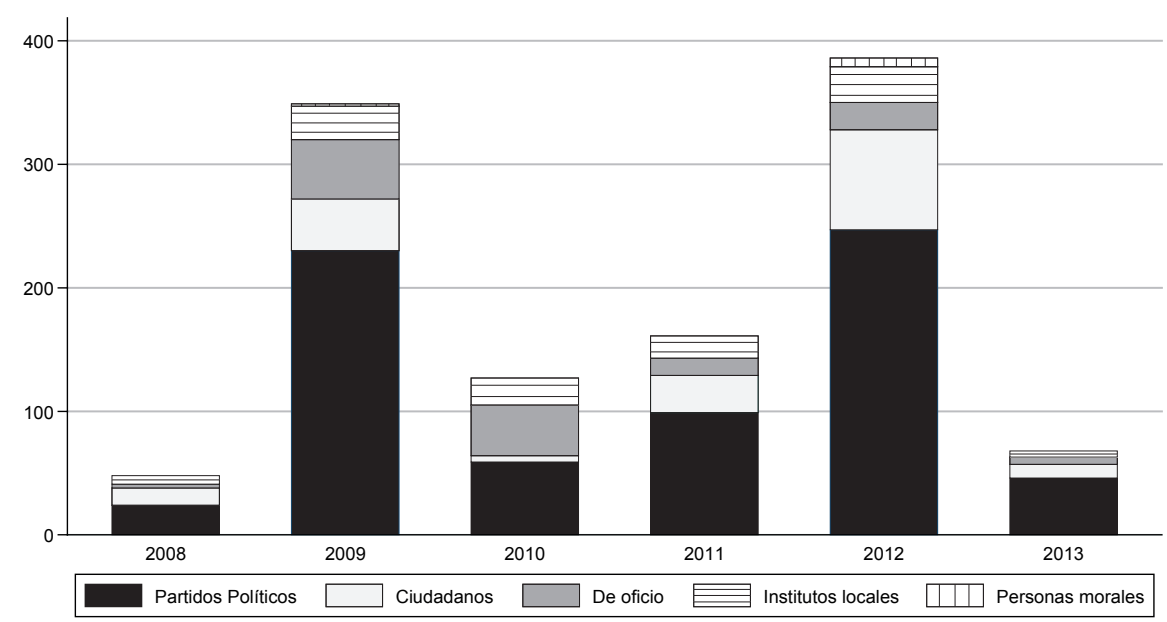

Fuente: elaboración propia con datos de la Dirección Jurídica del Instituto Nacional Electoral.

Con el objetivo de profundizar en la comprensión de lo que implicó para el IFE el ejercicio de sus funciones de carácter administrativo-jurisdiccionales, a continuación se presenta un balance de los actores que recurrieron al procedimiento especial sancionador y los tipos de asuntos que provocaron las denuncias.

Entre 2008 y 2013 se presentaron a nivel central un total de 1,139 procedimientos especiales. De ellos, $64.5 \%$ fueron recibidos en años en los que se celebraron jornadas electorales (2009 y 2012), 18.3\% en años de preparación e inicio de procesos electorales (2008 y 2011), y 17.2\% en años posteriores a la conclusión de ellos (2010 y 2013). Estos datos dan cuentan de un ciclo en el que la mayor parte del litigio - por conducto del procedimiento especial - es estimulado por la dinámica de las campañas electorales. Agrego, si bien aminora sustancialmente, el carácter litigioso no se extingue en periodos no electorales.

${ }_{17}$ Becerra, Ricardo, "Piensen en cargar a un elefante (y luego en el IFE)", Nexos, junio de 2011. 
Por su origen y naturaleza, el PES es un instrumento jurídico primordialmente empleado por los partidos políticos que protagonizan las actividades electorales tanto en periodo de campaña como fuera de ella. Con excepción de 2010, los partidos políticos han promovido cada año cuando menos el 50\% del total de PES recibidos a nivel central. Después de los partidos políticos, los ciudadanos han sido los litigantes más activos: el $16.1 \%$ de los casos fueron presentados por ellos, concentrándose su mayor parte en los años con jornadas comiciales. Los casos instaurados por las autoridades electorales representan en conjunto el $21.3 \%$. De este porcentaje, poco más de la mitad corresponde a procedimientos iniciados de oficio por el Instituto y el resto a expedientes derivados de quejas de institutos electorales locales.

\section{Gráfica 3}

Procedimientos especiales sancionadores por tema, 2008-2013

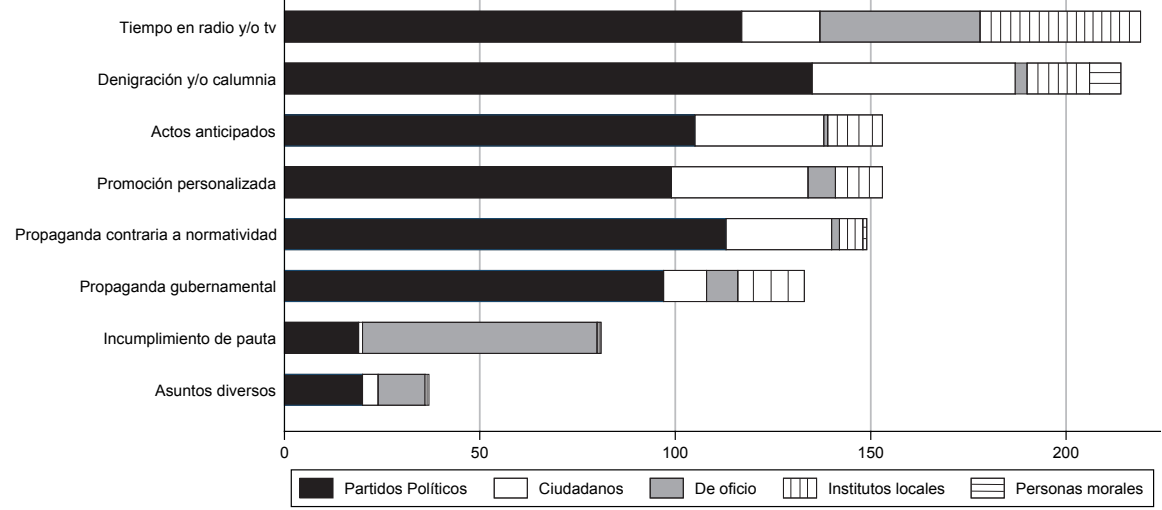

Fuente: elaboración propia con datos de la Dirección Jurídica del Instituto Nacional Electoral.

Los procedimientos especiales son originados por una gran diversidad de asuntos vinculados a la dinámica de las actividades partidarias dentro de procesos electorales o no. En cuanto a los temas se observa una diversidad importante, no solo en el tiempo sino en los actores que las promueven. Respecto de este aspecto, es de señalar que no existen faltas que concentren de manera sobresaliente los casos. Por el contrario, ninguno de los temas en los que se concentran las denuncias supera el $20 \%$ del total. Como se observa en la gráfica 3, la mayor parte de los casos se originan por presuntas faltas en materia de adquisición o contratación de tiempos en radio y televisión (19.2\%), seguidas de aquellas relacionadas 
con denigración o calumnias. A pesar de que estos dos temas son los más recurrentes, no es mayor la diferencia que existe con los casos motivados por supuestos incumplimientos a la transmisión de la pauta ordenada por el IFE (7.1\%).

\section{Gráfica 4}

Procedimientos especiales sancionadores por actor y tema, 2008-2013

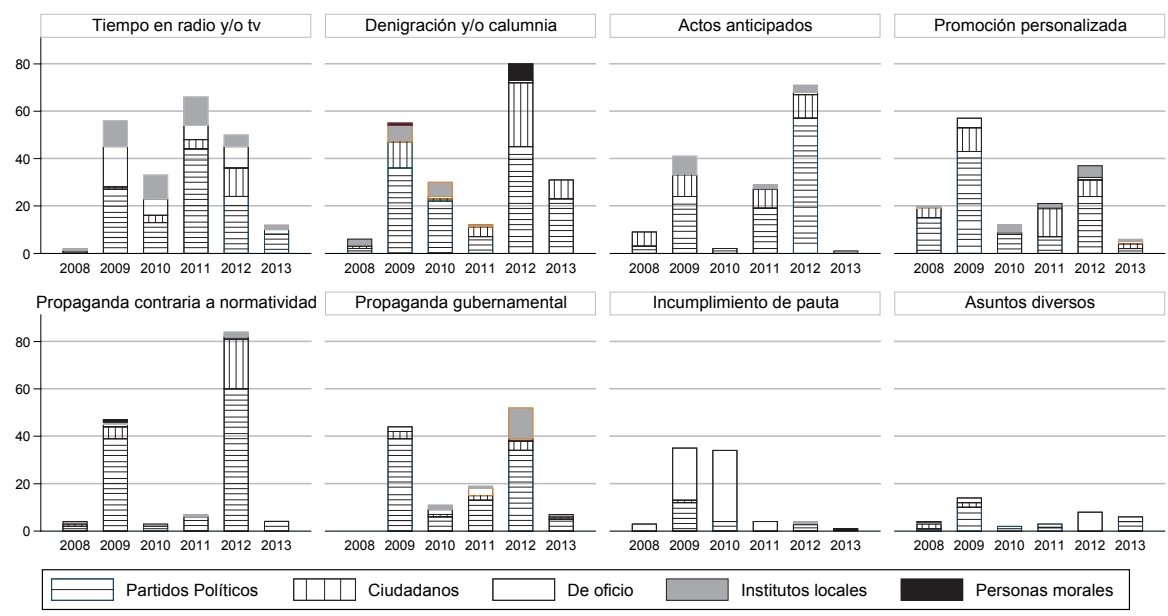

Fuente: elaboración propia con datos de la Dirección Jurídica del Instituto Nacional Electoral.

Ciertamente, la forma en que se distribuyen las denuncias por actores, años y plazos permite advertir cómo el litigio está condicionado tanto por la dinámica de los procesos electorales como por la naturaleza de los actores. Los procedimientos especiales promovidos por partidos políticos se distribuyen con cierto equilibro entre la diversidad de temas planteados, pero se concentran particularmente en años en los que se realizan campañas electorales, pero también proliferan las denuncias asociadas con actos anticipados de precampaña o campaña, la difusión de propaganda gubernamental en periodo prohibido, o la difusión de propaganda contraria a la normatividad electoral.

En contraste, los casos relacionados con incumplimientos de transmisión de las pautas, que ha iniciado tanto el IFE de oficio como los institutos electorales locales, tuvieron mayor recurrencia en 2009 y 2010 , años subsecuentes al inicio de la aplicación del nuevo modelo de comunicación política. De hecho, como se observa en la gráfica 4 , el volumen 
de este tipo de casos se redujo sustancialmente una vez que se consolidó este modelo en la vida política nacional.

Ahora bien, para finalizar este apartado es fundamental revisar en forma general cómo los procedimientos especiales han sido resueltos tanto en la sede administrativa como en la jurisdiccional vía recursos de apelación. Entre 2008 y 2013, se registraron a nivel central 1139 procedimientos especiales sancionadores. Una vez que se analizaron y acumularon estos procedimientos, el Consejo General emitió en total 913 resoluciones. De ellas, en uno de cada cuatro casos se declaró fundada la denuncia, infundada en poco más de la tercera parte, mientras que el $30.1 \%$ fueron desechadas.

Los casos vinculados a la asignación de tiempos en el nuevo modelo de comunicación política concentraron buena parte de las resoluciones fundadas. El $63.9 \%$ de las resoluciones vinculadas a procedimientos en las que investigaron incumplimiento de pautas se declararon fundadas; en tanto en los casos vinculados a la adquisición o contratación de tiempos en radio y/o televisión esta proporción fue de $40.1 \%$. Por el contrario, fueron infundados o desechados más de tres cuartas partes de los casos vinculados a la difusión de propaganda contraria a la normatividad, actos anticipados y denigración y/o calumnia.

\section{Gráfica 5}

Procedimientos especiales sancionadores por tema y sentido de la resolución, 2008-2013

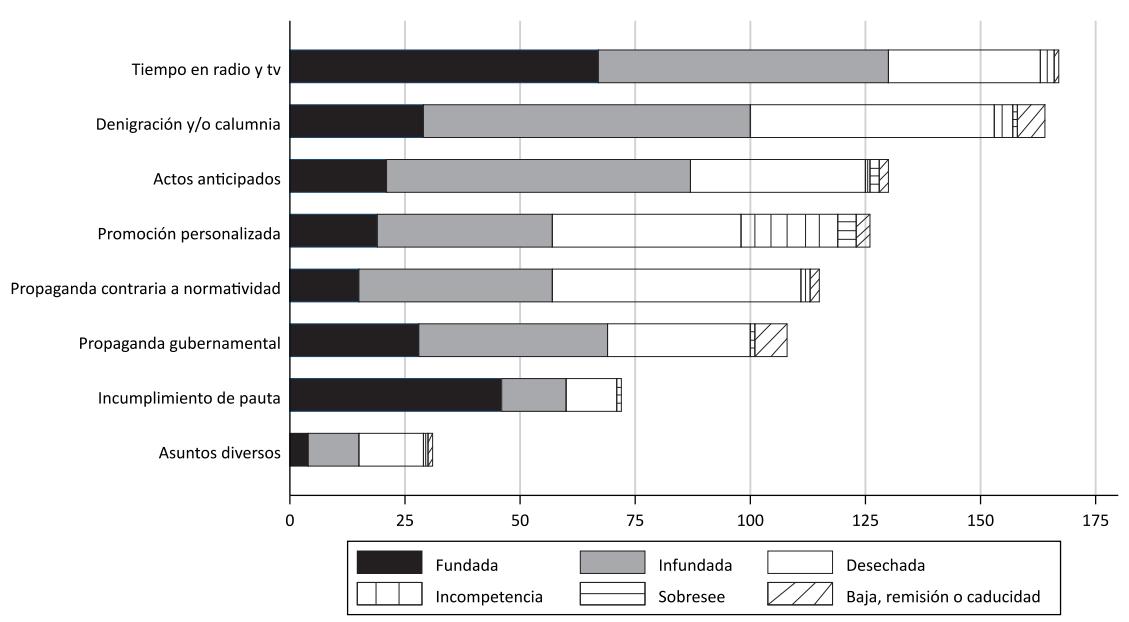

Fuente: elaboración propia con datos de la Dirección Jurídica del Instituto Nacional Electoral. 
El procedimiento especial sancionador ha sido un mecanismo eficaz para que la autoridad vigile el cumplimiento de sus atribuciones en materia de administración de los tiempos del Estado en radio y televisión. Una comparación de los datos de la gráfica anterior, con la información de las gráficas 3 y 4 , permite advertir, primero, que la mayor parte de los casos relativos al incumplimiento de pautas y a la adquisición o contratación de tiempos en radio y/o televisión, fueron iniciados de oficio por la autoridad $y$, segundo, que éstos son los que más frecuentemente derivan en resoluciones fundadas.

En contraste, buena parte de los procedimientos iniciados de denuncias de partidos políticos culminan ya sea en desechamientos o en resoluciones infundadas. Los datos presentados en este artículo muestran que, efectivamente, el procedimiento especial sancionador ha sido parte de las estrategias empleadas por los partidos políticos para llevar a arenas administrativo-judiciales el conflicto inherente a sus campañas. Esto, como más adelante se profundizará, ha hecho compleja la labor de una autoridad cuya función primaria es de carácter administrativo y no jurisdiccional. ${ }^{18}$

Ciertamente, como ha sido señalado por el doctor Lorenzo Córdova, los retos que se enfrentaron en el Proceso Electoral Federal 2005-2006 estuvieron relacionados con un déficit de instrumentos legales para prevenir y sancionar conductas que vulneraban la ley. La creación del procedimiento especial, si bien amplió los canales institucionales para procesar el conflicto político, también abrió un nuevo flanco para la autoridad administrativa. En la evolución del procedimiento especial sancionador se pueden observar los problemas derivados de la falta de acompañamiento al IFE tanto de otras entidades públicas como de partidos políticos. Así también, la historia de este procedimiento permite advertir las dificultades que ha tenido la propia autoridad. Éstas han sido visibles por ejemplo en decisiones como aquella en la que decretó el sobreseimiento en un procedimiento que proponía "sancionar a la televisoras que habían «empaquetado» spots e incluido una serie de cortinillas en las que acusaban a la reforma electoral y al IFE de interrumpir la programación". ${ }^{19}$

El procedimiento especial sancionador ha implicado un volumen considerable de trabajo tanto para la autoridad administrativa como para la

18 Para un análisis de este tema, véase Zavala Arredondo, Marco Antonio, "A salto de mata. Los procedimientos especiales sancionadores y el proceso electoral 2011-2012", Revista Mexicana de Derecho Electoral, núm. 4, enero-junio de 2013.

19 Córdova Vianello, Lorenzo, op. cit., p. 18. 
jurisdiccional. Conforme a los datos de la Dirección Jurídica del Instituto Federal Electoral, entre 2008 y 2014, la Sala Superior del TEPJF ha resuelto 771 recursos de apelación derivados de resoluciones del Consejo General en materia de procedimientos especiales iniciados ante el IFE en el periodo 2008-2013. En cuatro de cada diez casos, la Sala Superior ha confirmado la resolución. Sin embargo, cuatro de cada diez casos ha dado pie a sentencias en las que se revoca el sentido original de la resolución.

Al cotejar la información de las resoluciones del IFE con las de las TEPJF, se observa, primero que, a pesar de lo que está en juego en ellas, no en todos los casos los actores han acudido a la instancia jurisdiccional con la intención de revertir lo determinado por la instancia administrativa. En segundo lugar, se advierte que la proporción de sentencias que se confirman y revocan ha permanecido relativamente estable a lo largo del tiempo.

\section{Gráfica 6}

Procedimientos especiales sancionadores.

Recursos de apelación por sentido de la resolución, 2008-2013

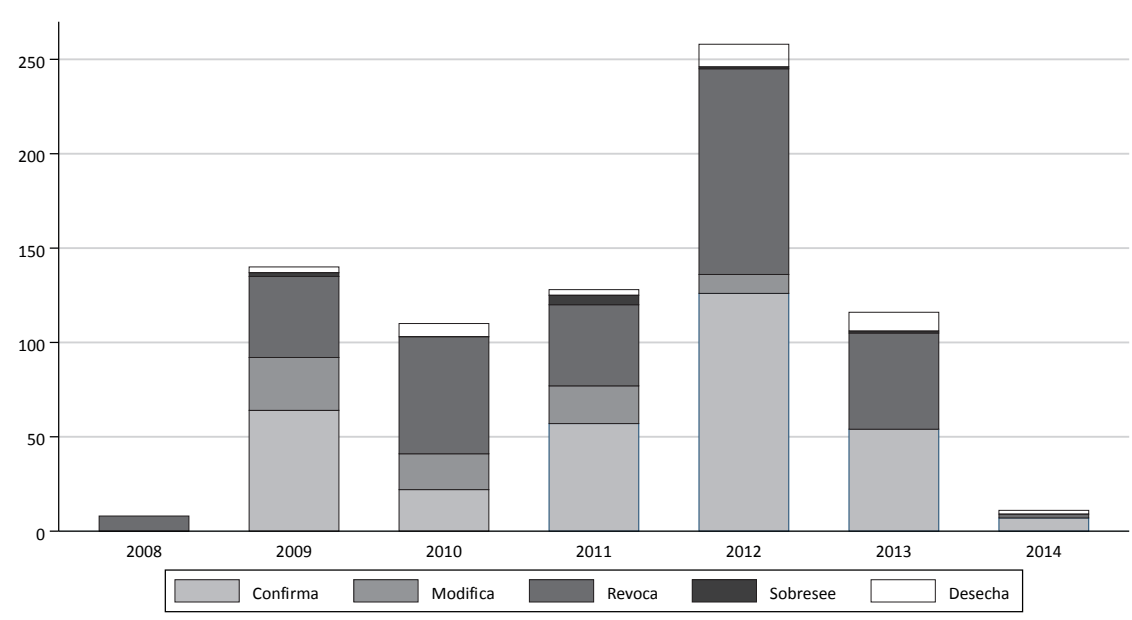

Fuente: elaboración propia con datos de la Dirección Jurídica del Instituto Nacional Electoral.

Un estudio reciente que, entre otras cuestiones, da cuenta de lo ocurrido en la Sala Superior en los casos derivados del Proceso Electoral Federal 2011-2012, muestra que buena parte de la revocaciones del TEPJF estuvieron relacionadas con violaciones al artículo 134 constitucional, lo cual 
indica lo complejo de vigilar el cumplimiento de los preceptos de este artículo ante la ausencia de una ley reglamentaria. Como señala marco Zavala, "sin parámetros claros, es fácil que existan discrepancia entre los criterios, empezando por el papel de las autoridades electorales en un mandato constitucional que trasciende lo electoral para comprender toda actividad de los órganos estatales". ${ }^{20}$

La dinámica propia de la resolución de los procedimientos especiales y de los recursos de apelación derivados de ellos ha involucrado el desarrollo de importantes esfuerzos por generar criterios y desarrollar una relación armónica entre la instancia administrativa y la jurisdiccional. En especial, al interior del Instituto Federal Electoral, la atención de los procedimientos especiales cobró una importancia superlativa la cual es visible en la labor interpretativa que ha realizado, como en la carga de trabajo que ha supuesto. La siguiente sección ofrece un recuento de estas cuestiones.

III. El procedimiento especial sancionador en la práctica: desarrollo de criterios e implicaciones institucionales

Como se ha visto, la resolución de los procedimientos especiales sancionadores implicó un vasto trabajo para el Consejo General. Ahora bien, esto no solo se refleja en la cantidad y diversidad de procedimientos de este tipo que fueron atendidos, así como en el número de sesiones del Consejo que fue necesario realizar para desahogarlos. Como se explicará en esta sección, no es menos relevante el enorme esfuerzo institucional que implicó la creación de un amplio andamiaje jurídico a través del desarrollo de criterios interpretativos.

En efecto, debido a la novedad de estos casos, los órganos encargados de su sustanciación y resolución se vieron inevitablemente enfrentados a vacíos normativos y problemas diversos que fue necesario ir solventando sobre la marcha. En esta labor, el IFE se vio en la necesidad de ir definiendo criterios, que a menudo fueron enriquecidos pero también cuestionados por la tarea jurisprudencial del Tribunal Electoral del Poder Judicial de la Federación. En no pocos casos, esta labor conjunta entre las autoridades administrativa y jurisdiccional jugaba en contra del carácter expedito de los procedimientos pues implicaba impugnaciones

20 Zavala Arredondo, Marco Antonio, op. cit., p. 250. 
y devoluciones por parte del Tribunal, de las decisiones de una autoridad electoral cuya función sustantiva no era jurisdiccional. Sea como fuere, puede decirse que a fin de cuentas se estableció una relación de sinergia entre ambas instancias que, no exenta de complejidades, dio paso a la elaboración de criterios específicos en muy diversas áreas. A continuación mencionaremos algunos ejemplos de los retos que debió enfrentar el Instituto en la definición de esos criterios.

Por ejemplo, para el IFE fue necesario ir desarrollando criterios que permitieran distinguir los actos anticipados de precampaña de los de campaña. Esto resultaba fundamental debido al peso de la circunstancia de tiempo en la valoración de los procedimientos, pues las prohibiciones contenidas en la normatividad electoral no son las mismas para periodos fuera del proceso electoral que en precampaña, intercampaña y campaña. De hecho tienden a incrementarse conforme se acerca el periodo de campaña electoral. A pesar de que se avanzó en la definición de criterios para diferenciar los actos anticipados de campaña y precampaña, persistía una cuestión de fondo que no estaba clara en la normatividad: si el Instituto tenía atribuciones para conocer y en su caso sancionar infracciones de este tipo en cualquier momento o solamente durante el proceso electoral.

Otro tema por demás controvertido fue el de las expresiones consideradas como denigración y calumnia, pues resultaba sumamente difícil la definición de criterios que permitieran esclarecer qué debe entenderse por denigración y calumnia. Casos parecidos eran aquellos asuntos relacionados con propaganda integrada, en los que la difusión de propaganda electoral se realiza en espacios o tiempos no convencionales, destinados para la inserción de propaganda comercial. El Consejo General conoció y resolvió el caso de un programa de televisión (una telenovela) en donde uno de los actores portaba en la ropa propaganda electoral. El Consejo General determinó tal conducta como contraria a las normas de propaganda electoral y resolvió sancionar. El asunto fue impugnado, el Tribunal Electoral confirmó la determinación del Instituto.

Otros criterios se definieron a través de impugnaciones que el TEPJF resolvió en un sentido contrario al del Instituto Federal Electoral. Incluso algunos aspectos de carácter procedimental se fueron esclareciendo por esta vía. Por ejemplo, en el primer caso que resolvió el Consejo General relacionado con la transmisión de propaganda no ordenada por el IFE, se determinó que, aun cuando se había acreditado la infracción, no era posible establecer ningún tipo de sanción, debido a que no se contaba con el contrato o documento que permitiera acreditar la responsabilidad del denunciado. Por el contrario, en septiembre de 2009 el Tribunal Elec- 
toral resolvió que para la configuración de dicha infracción es irrelevante la existencia de un contrato que documente el acuerdo. La sola difusión indebida de la propaganda actualiza la violación del artículo 41 constitucional, que prohíbe la contratación o adquisición, con fines político-electorales, de tiempos en radio y televisión, infracción que puede derivar lo mismo de un acuerdo de voluntades que de un acto unilateral.

En otro caso altamente controvertido, relacionado con propaganda electoral difundida a través de entrevistas, el Consejo General determinó que, por un lado, efectivamente se trataba de propaganda electoral; por el otro que sin embargo no era posible sancionar dado que no se contaba con el contrato que documentara el acuerdo por el que se concertó la entrevista. La Sala Superior del TEPJF confirmó el criterio antes referido: que la existencia de un contrato no es un elemento necesario para acreditar la comisión de la infracción ni para sancionarla. En cuanto al fondo, la determinación de la Sala Superior fue contraria a la del Consejo General, estableció que la prohibición del artículo constitucional 41, base iii, apartado A, párrafo segundo, no comprende los tiempos de radio y televisión empleados para la difusión de los ejercicios periodísticos genuinos, que en todo caso constituyen una manifestación del ejercicio de la libertad de expresión e información.

Por último, es importante advertir que durante la sustanciación de los procedimientos especiales sancionadores, determinar la calificación de la infracción resultó particular y recurrentemente complejo para el Instituto. En el ya abrogado Cofipe se establecían las siguientes circunstancias para ejercer la facultad de la autoridad para establecer la sanción:

1) La gravedad de la responsabilidad en que se incurra y, en atención al bien jurídico tutelado, la conveniencia de desincentivar prácticas que infrinjan, en cualquier forma, las disposiciones de este Código o las que se dicten con base en él.

2) Las circunstancias de tiempo, modo y lugar de la infracción.

3) Las condiciones socioeconómicas del infractor.

4) Las condiciones externas y los medios de ejecución.

5) La reincidencia en el incumplimiento de obligaciones.

6) En su caso, el monto del beneficio, lucro, daño o perjuicio derivado del incumplimiento de obligaciones.

Una parte muy considerable de las resoluciones del Consejo General que fueron impugnadas ante el TEPJF por aspectos relacionados con la individualización de la sanción, se devolvieron al Instituto bajo el argumento 
de que la autoridad no argumentó por qué se consideraron algunos de estos elementos y no otros, o bien, por qué se fijó la sanción en determinada cantidad pecuniaria y no otra. Además, en ese proceso de analizar y revisar caso por caso, la autoridad jurisdiccional ha determinado nuevos criterios para la individualización de la sanción como son: bien jurídico tutelado lesionado, singularidad o pluralidad de faltas, existencia de intencionalidad, tipo de contienda electoral, número de impactos, tiempo de difusión, etapa del proceso en que se llevó a cabo la conducta, medio comisivo, cobertura, impacto en el proceso electoral, entre otros. Criterios con los que el Consejo General del Instituto no contaba previamente a la individualización de las sanciones.

Con estos breves apuntes hemos querido ilustrar algunas dificultades que enfrentaron las autoridades electorales al definir criterios. Ahora bien, es fundamental advertir que, como se señaló antes, la complejidad de esta función administrativa-jurisdiccional se tradujo en una importante carga de trabajo para el Consejo General del Instituto Federal Electoral. Evidentemente, la indefinición de los criterios en muchos de sus aspectos, así como la consecuente dinámica de ida y vuelta que se estableció con el TEPJF, precisaron de muchas horas de deliberación intensiva en el seno del Consejo General, como puede verse a continuación.

Así, en el marco del Proceso Electoral Federal 1999-2000, el Consejo General del IFE celebró 20 sesiones, con una duración global de 102 horas. Tres años después, el número de sesiones descendió a 18 y la duración total a 99 horas. Para organizar el proceso de 2005-2006, el Consejo General se reunió en 32 ocasiones, las cuales sumaron poco más de 103 horas de trabajo. En la gráfica siguiente puede apreciarse con claridad cómo, a partir de la instauración del procedimiento especial sancionador, el número de sesiones y su duración incrementa sustancialmente para los procesos electorales federales de 2008-2009 y 2011-2012. En el mismo sentido, las sesiones se vuelven mucho más frecuentes: el número de días que transcurre entre una y otra se reduce a menos de la mitad después de 2005-2006. 


\section{Gráfica 7}

\section{Sesiones del Consejo General durante procesos electorales}
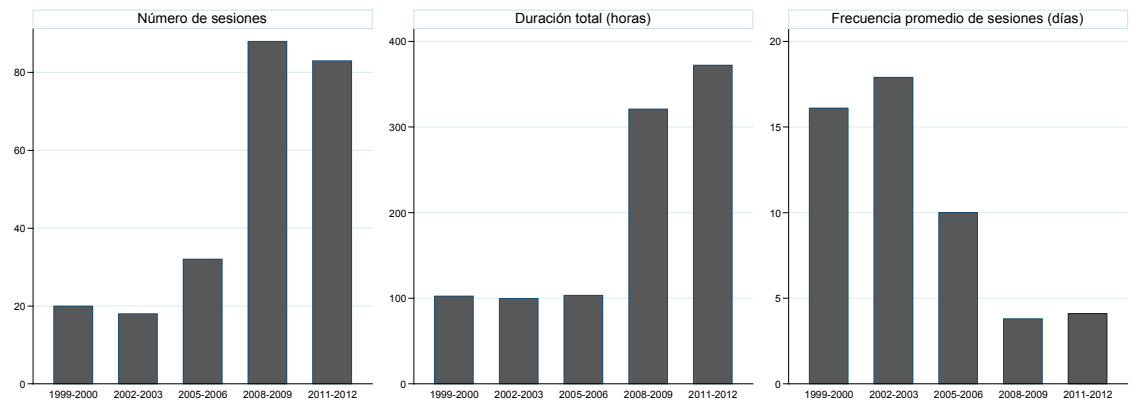

Fuente: IFE, Informe sobre la implementación de la reforma electoral durante el proceso 2008-2009, México, IFE, 2010; IFE, Memoria del Proceso Electoral Federal 2009-2010, México, IFE, 2013; IFE, Memoria del Proceso Electoral Federal 2011-2013, México, IFE, 2013.

En los procesos electorales 2008-2009 y 2011-2012, una vez incorporado el procedimiento especial al régimen constitucional, legal y reglamentario en materia electoral, y por lo tanto definidas las reglas procesales y competenciales correspondientes, el Instituto celebró 88 y 83 sesiones respectivamente, multiplicándose además el número de horas que el Consejo General dedicó a acordar y resolver los asuntos presentados a su conocimiento. En efecto, como resultado de las nuevas atribuciones que la reforma electoral de 2007-2008 otorgó al IFE, su máximo órgano de dirección vio multiplicado su trabajo y tuvo que sesionar con mucha mayor frecuencia para desahogar los asuntos bajo su jurisdicción. De realizar una sesión en promedio cada 10 días durante el proceso de 2005-2006, en los dos más recientes procesos electorales, el Consejo General tuvo que reunirse en promedio una vez cada cuatro días.

El Instituto Federal Electoral ejerció con oportunidad, rigor técnico, transparencia e imparcialidad la función administrativo-jurisdiccional que le fue encomendada. La complejidad y dinamismo de las contiendas electorales hicieron que esta función se convirtiera no sólo en un aspecto clave en el cumplimiento de sus encomiendas constitucionales, sino para la preservación de la institucionalidad de la vida democrática.

La complejidad y el propio dinamismo de las contiendas políticas en un contexto de amplia regulación provocaron, sin embargo, que los cauces litigiosos fueran adquiriendo mayor peso en las propias estrategias de los actores políticos. El hecho de que el $61.9 \%$ de los procedimientos especiales hayan sido instaurados por partidos políticos da cuenta de este 
fenómeno y ello a su vez, muestra que esta labor fundamental de dirimir conflictos ha sido realizada con los propios actores de las denuncias participando en las deliberaciones, con el inevitable efecto de politizar decisiones de carácter técnico y jurídico.

La reforma electoral de 2014 rediseñó parcialmente la justicia administrativa de carácter electoral. El objetivo de las modificaciones constitucionales y legales fue trasladar la resolución de los procedimientos expeditos a las instancias especializadas en justicia electoral y, así, eliminar una fuente de distorsión de las actividades de la autoridad administrativa. En este tema específico, la reforma presenta un panorama que luce positivo pero que, como se explicará en la siguiente sección, también supone importantes desafíos de ingeniería procesal e institucional que deberán ser atendidos con oportunidad.

\section{El procedimiento especial sancionador en la reforma constitucional de 2014}

La reforma constitucional en materia política-electoral, publicada en el Diario Oficial de la Federación el 10 de febrero de 2014 tiene sus claroscuros. Si bien algunos de sus aspectos contribuirán a mejorar las condiciones de equidad y certeza en los procesos electorales federales y locales, en otros implica diversos retos cuya solución no se antoja fácil. En el caso del PES, la reforma contiene avances fundamentales, que ayudarán a solucionar o por lo menos atenuar algunos de los problemas que señalamos arriba. Sin embargo, existen también algunos temas problemáticos y zonas de incertidumbre que quedaron pendientes de resolver.

El PES quedó regulado en un capítulo específico (Cuarto) del Libro Octavo, Título Primero, de la nueva Ley General de Instituciones y Procedimientos Electorales (LGIPE), que se deriva de la reforma constitucional y que se encuentra en vigor desde el 24 de mayo del mismo año. En lo que respecta al PES, el aspecto más sobresaliente de la reforma es el nuevo texto de la base III del artículo 41, apartado D, que le da al nuevo Instituto Nacional Electoral la atribución de investigar,

mediante procedimientos expeditos en los términos de la ley... las infracciones a lo dispuesto en esta Base e integrará el expediente para someterlo al conocimiento del Tribunal Electoral del Poder Judicial de la Federación. En el procedimiento, el Instituto podrá imponer, entre otras medidas cautelares, 
la orden de suspender o cancelar de manera inmediata las transmisiones en radio y televisión, de conformidad con lo que disponga la ley.

La LGIPE reafirma lo que indicaba el nuevo texto constitucional: que ya no será la autoridad administrativa electoral, sino el Poder Judicial el encargado de resolver los procedimientos expeditos. Las atribuciones del INE en materia del PES se circunscriben a la integración del expediente original formado con motivo de la denuncia y del informe circunstanciado respectivo, que deberán ser remitidos a una Sala Especializada del TEPJF de nueva creación. Recibido el expediente en la Sala el presidente de la misma lo turnará al magistrado ponente que corresponda, quien deberá:

- Verificar el cumplimiento por parte del Instituto de los requisitos previstos en la ley y, en su caso, radicar la denuncia.

- En caso de advertirse omisiones o deficiencias en la integración del expediente o en su tramitación, realizar u ordenar al Instituto la realización de las diligencias necesarias, determinando el plazo para llevarlas a cabo. De persistir la violación procesal el magistrado ponente podrá imponer las medidas de apremio necesarias.

- Una vez que se encuentre debidamente integrado el expediente, el magistrado ponente deberá someter a consideración del pleno de la Sala Especializada el proyecto de sentencia, dentro de las 48 horas siguientes contadas a partir de su turno.

- En sesión pública, el Pleno de esta Sala deberá resolver el asunto en un plazo máximo de 24 horas contadas desde la distribución del proyecto de resolución.

- Las sentencias que resuelvan el PES podrán declarar la inexistencia del objeto de la queja o denuncia y, en su caso, revocar las medidas cautelares que se hubieren impuesto; o bien imponer las sanciones que resulten procedentes.

Ahora bien, aunque es claro que la facultad de resolver los PES ha quedado fuera de la esfera de atribuciones del Instituto, en la nueva legislación secundaria persisten ciertas imprecisiones sobre los alcances efectivos del INE en la atención de estos procedimientos. Sobre esto volveremos más adelante, por lo pronto merece la pena enlistar los aspectos más relevantes del procedimiento, como quedó definido en la LGIPE. ${ }^{21}$

${ }^{21}$ Aquí nos concentraremos en las denuncias interpuestas ante los órganos centrales del INE, pues son las que han dado origen a los problemas señalados en el apartado an- 
La nueva legislación define el tipo de conductas que pueden dar lugar al procedimiento especial, que son las mismas que definía el extinto Cofipe, a saber, aquellas que contravengan: lo establecido en la Base III del artículo 41 o en el octavo párrafo del artículo 134 de la Constitución; las normas sobre propaganda política o electoral; o que constituyan actos anticipados de precampaña o campaña. ${ }^{22}$

Ahora bien, la LGIPE crea un órgano especializado, la Unidad Técnica de lo Contencioso Electoral que, adscrita a la Secretaría Ejecutiva, será la encargada de atender este tipo de denuncias y examinarla junto con las pruebas aportadas. Es decir que esta Unidad Técnica será la encargada de sustanciar los PES bajo el siguiente procedimiento:

- La denuncia será desechada de plano, sin prevención alguna, cuando: no reúna los requisitos indicados en el párrafo 3 del artículo 470; los hechos denunciados no constituyan una violación en materia de propaganda político-electoral; el denunciante no aporte ni ofrezca prueba alguna de sus dichos, o la denuncia sea evidentemente frívola.

- No serán admitidas más pruebas que la documental y la técnica; esta última será desahogada siempre y cuando el oferente aporte los medios para tal efecto en el curso de la audiencia.

- La Unidad Técnica de lo Contencioso Electoral deberá admitir o desechar la denuncia en un plazo no mayor a 24 horas posteriores a su recepción. En caso de desechamiento, notificará al denunciante su resolución dentro del plazo de doce horas.

terior de este ensayo. Cabe señalar no obstante que la LGIPE preserva la atribución de los vocales ejecutivos de las Juntas Locales y Distritales de recibir las denuncias que, en el ámbito de su demarcación territorial, tengan como motivo conductas presuntamente ilegales referidas a: la ubicación física o al contenido de propaganda política o electoral impresa; de aquélla pintada en bardas; de cualquier otra diferente a la transmitida por radio o televisión; así como cuando se refieran a actos anticipados de precampaña o campaña relacionados con ese tipo de propaganda. En estos casos, el Vocal Ejecutivo ejercerá las facultades señaladas para la Secretaría Ejecutiva, incluyendo la celebración de la audiencia y el turno del expediente respectivo a la Sala Especializada del Tribunal Electoral. Si en alguno de estos supuestos, especificados en el párrafo 1 del artículo 474, la conducta denunciada constituye una infracción generalizada o reviste gravedad, la Secretaría Ejecutiva del Instituto podrá atraer el asunto.

22 El artículo 471 de la LGIPE precisa que "los procedimientos relacionados con la difusión de propaganda que se considere calumniosa sólo podrán iniciarse a instancia de parte afectada. Se entenderá por calumnia la imputación de hechos o delitos falsos con impacto en un proceso electoral". 
- Admitida la denuncia, la audiencia de pruebas y alegatos tendrá lugar dentro del plazo de 48 horas posteriores a la admisión. Dentro del mismo plazo la Unidad Técnica de lo Contencioso, de considerarlo necesario, propondrá a la Comisión de Quejas y Denuncias la adopción de medidas cautelares.

- Celebrada la audiencia, la Unidad Técnica de lo Contencioso deberá turnar a la Sala Especializada del Tribunal, de forma inmediata, el expediente completo, exponiendo en su caso las medidas cautelares y demás diligencias que se hayan llevado a cabo, así como un informe circunstanciado

- Dicho informe circunstanciado deberá contener: la relatoría de los hechos que dieron motivo a la queja o denuncia; las diligencias que se hayan realizado por la autoridad; las pruebas aportadas por las partes; las demás actuaciones realizadas, y las conclusiones sobre la queja o denuncia.

Hay varias cosas a destacar de este nuevo modelo de PES. Llama la atención no solo que el Consejo General del Instituto Nacional Electoral ya no tiene a su cargo la resolución de los PES; más aún, la Comisión de Quejas y Denuncias tampoco está involucrada en el proceso, con excepción de su atribución de decidir sobre las medidas cautelares propuestas por la Unidad Técnica y de recibir copia de los informes circunstanciados que se remitan a la Sala Especializada.

Como puede apreciarse, ni el Consejo General ni sus integrantes tendrán ya injerencia sustantiva sobre ninguna de las etapas del procedimiento. Esto tendrá por lo menos dos efectos positivos. En primer lugar, la carga del Consejo de asuntos por desahogar se reducirá significativamente, pues ya sólo tendrá que ocuparse, en materia jurisdiccional, de los procedimientos sancionadores ordinarios. En segundo lugar, y más importante, los PES ya no serán un motivo de deliberación en el Consejo, por lo que éste dejará de ser el foro de contienda partidista en que se había convertido, como se ha insistido en este texto. Sin duda esto ayudará a que aminoren las tensiones entre el árbitro electoral y los partidos políticos durante los procesos electorales federales a cuyo incremento había contribuido durante los últimos años, el PES.

Esta "despolitización" del tramo del PES que corresponde al INE podría implicar, a su vez, que los partidos tengan menos incentivos políticos para interponer ese tipo de denuncias, lo que podría ayudar a reducir la judicialización de las contiendas electorales federales. Cuando menos, el nuevo modelo separa al juez y a la parte (que antes estaba integrada a la 
instancia resolutoria, el Consejo General del IFE), de modo que el espacio de la deliberación jurisdiccional será solo eso, y ya no, además, un foro de contienda y hasta de campaña política.

Por último, el hecho de que el tribunal de última instancia sea también el encargado de resolver los PES ayudará a la definición de criterios más estables, firmes y consistentes, en beneficio de la legalidad y certidumbre jurídica. Bajo el modelo anterior, la inevitable diferencia de criterios entre la autoridad administrativa electoral y la jurisdiccional, generaba a menudo un constante vaivén de los casos que difería el establecimiento de pronunciamientos sobre el fondo de los asuntos y, en consecuencia, la definición de principios orientadores para denuncias futuras. Ahora será la instancia propiamente jurisdiccional la que asumirá el monopolio de la definición de criterios, en favor de una justicia electoral más expedita y certera.

Sin embargo, es necesario advertir de dos posibles riesgos en el nuevo modelo. En primer lugar, es importante que la facultad que atribuye la LGIPE a la Unidad Técnica de lo Contencioso Electoral, en el sentido de elaborar las conclusiones de la queja o denuncia, no se asemeje en absoluto a un proyecto de resolución. Por las razones expuestas en el párrafo anterior, resulta indispensable que la definición y aplicación de criterios sea una función exclusiva del Tribunal Electoral. La labor de la Unidad debe ser, como su nombre lo indica, exclusivamente técnica y nunca interpretativa, y su función debe tener una frontera nítida: limitarse a la integración del expediente y las pruebas.

Por último, existe también el riesgo de que el TEPJF devuelva al INE, con más frecuencia de lo que sería deseable, los expedientes por razones procedimentales, riesgo que incrementa por el solo hecho de que nos encontramos ante un nuevo modelo de procedimiento especial sancionador. Este escenario sería indeseable tanto para las autoridades administrativas y jurisdiccionales, como para los partidos políticos involucrados, pues iría en contra de los principios constitucionales de justicia expedita y equidad e igualdad en la contienda electoral, que de hecho son el fundamento último del PES. Evitar que esto ocurra requiere de una intensa colaboración institucional entre el INE y el TEPJF, que idealmente podría traducirse en la elaboración de un protocolo conjunto de investigación y en el acompañamiento presencial, por parte de la autoridad jurisdiccional, de cada una de las etapas del PES que corresponden al Instituto. 


\section{Conclusión}

En México, durante los últimos 25 años, ha habido un proceso de redistribución y definición de competencias entre el Poder Judicial y el organismo autónomo electoral, en lo que se refiere a la facultad de conocer, tramitar y resolver denuncias relacionadas con infracciones a la normatividad electoral. Sin duda éste ha sido un tema central de la transición democrática, no necesariamente el más visible, pero de consecuencias trascendentales para la generación de condiciones de equidad y certidumbre jurídica en la contienda política.

Desde sus orígenes el Instituto Federal Electoral tuvo la atribución de instaurar procedimientos para conocer de las infracciones cometidas por los partidos políticos. Sin embargo, de acuerdo con el Cofipe de 1990, era la Sala Central del Tribunal Federal Electoral la responsable de definir e imponer las sanciones que correspondiesen. Solo con la reforma constitucional de 1996 le fue conferida al IFE la atribución de tramitar, sustanciar y resolver procedimientos administrativos, así como imponer las sanciones correspondientes. En la medida en que la contienda electoral se volvió más competitiva y conflictiva, fue necesario ensanchar esta atribución e instaurar un procedimiento de carácter expedito, como hizo la sentencia SUP-RAP-17/2006 del Tribunal Electoral y confirmó la reforma electoral de 2007-2008. En este sentido, la reforma constitucional de 2014 busca instaurar un nuevo equilibrio: en el caso de los procedimientos especiales sancionadores la facultad de resolución se devuelve al tribunal especializado en materia electoral del Poder Judicial.

En este tema, la más reciente reforma político-electoral representa un acierto. Quizá lo más relevante sea el hecho de que el Consejo General del INE tendrá una injerencia mucho más limitada en los que respecta al procedimiento especial sancionador. Esto permitirá reducir sustancialmente su carga de trabajo y —-mucho más importante- su carga política, pues, como se ha argumentado en este ensayo, las discusiones sobre procedimientos especiales se habían convertido en una especie de foro para la contienda interpartidista. El Consejo General debe ser ante todo, y en virtud de su carácter neutral y técnico, una instancia de tránsito y resolución del conflicto político, y nunca un apéndice del escenario de las campañas políticas.

Retirar del ámbito de competencias del INE la resolución de los PES es, pues, un aspecto positivo que podría contribuir a disminuir el carác- 
ter litigioso de las campañas. En primer lugar, los beneficios políticos -y en consecuencia los incentivos- de impugnar las resoluciones serán menores para los actores políticos, pues ya no habrá un foro público, como era el Consejo, para dirimir estas controversias. En segundo lugar, dado que la definición de criterios, la resolución y las instancias de impugnación recaerán todas en el Poder Judicial, es de esperar deseable que las devoluciones sean menos y que la definición de criterios sea más ágil y estable, en beneficio de la certidumbre política y el carácter expedito de la justicia electoral.

Es importante advertir que estas promesas de la reforma solo podrán actualizarse plenamente bajo dos condiciones: por un lado, en la práctica debe mantenerse con toda nitidez la división del trabajo entre el INE y el TEPJF, de suerte que las conclusiones de la denuncia que elabore la Unidad Técnica de lo Contencioso Electoral no sugieran en absoluto el sentido de la resolución; por otro lado, será crucial establecer una efectiva dinámica de colaboración con el Tribunal, que garantice que los elementos que integre el INE sean pertinentes y suficientes para que la autoridad jurisdiccional emita sus resoluciones, y evitar así devoluciones y dilaciones en la impartición de justicia electoral. En este sentido, la creación conjunta de instrumentos que estructuren los procedimientos a realizar por cada instancia en cada una de las etapas del proceso podrá configurarse como un pilar de la relación armónica que debe privar entre ambas instituciones.

Si se cumplen estas condiciones, la reforma político-electoral en materia de justicia electoral podría representar un hito en la última década del cambio político en México, al ofrecer condiciones para la impartición de una justicia electoral más expedita, cierta y neutral. 